\title{
Intra and Inter Party-Conflicts: Implications for Good Governance in the Niger Delta Region
}

\author{
Nmom, Ogudia Christopher \\ Social Studies Department, Ignatius Ajuru University of Education \\ Rumuolumeni, Port Harcourt
}

\section{Doi:10.5901/mjss.2013.v4n3p673}

\begin{abstract}
The return of democracy in Nigeria in 1999 has been with mixed blessing for many Nigerians, but for the Niger Deltans, it is blurred and full of uncertainties. Evidence abound that other regions of the country have witnessed a robust and boisterous political participation with some level of democratic dividend. These regions have allowed free choice of individuals to belong to any party and this has given them some variegated benefits. Contrary to this, in Niger Delta Region, the story is different; participants and politician have been initiated to belong to a party because of the selfish drive of some few and plausibly due to late entry into partisan politics by many from the region. The paper tries to explore that the beauty of any liberal democracy and good governance, lies in the active inter and intra party conflicts. It goes further to suggest that only good governance through participation in such party conflicts can true real dividend of democratic participation accrue to the Niger Delta people.
\end{abstract}

Keywords: Intra Party Conflict Inter-Party Conflict and Good Governance.

\section{Introduction}

In discussing the topic it would be worthwhile to espouse basic principles of democracy and politics within which the intra and inter party conflicts operate. Let us take up the concept of DEMOCRACY, we need not say that democracy is an essentially contested concept in the sense that the way one defines it would betray one's beliefs, personal outlook and political experiences. But amongst all, the most commonly accepted and universal is that "democracy is the government of the people by the people and for the people". Though superficially defined, the practical implication of democracy or the reality is that democracy is the government of a privilege few who organized themselves into political parties with the vested interest of protecting their cherished values and obtain state control (Otten, 1981). This definition correctly fits the practice in most developing countries who tends to borrow the practice from the West, especially Nigeria.

Technically and operationally, democracy can be seen as a system of state control involving institutionalized methods by which the ruled can affect the governing elites where individual citizens and minority groups are protected by law from the arbitrary governmental interference, and where the normative tendency strains toward a wide distribution of power (Otten, 1991). Also to be noted further is that within government itself, power is divided into competing factions. The legislative function of making law is separated from the executive of laws, and an independent judiciary make sure that laws themselves are constitutional and they are properly enforced.

Politics on its own therefore is a struggle for power; and control of the state is the price of victory. As a battle field, the strongest usually wins but as in battle, it is not always clear who is stronger, what is the source of strength, and what is a victory, these are relatives. Furthermore, luck; along with sheer power often play a role.

Politics is the battlefield, albeit normally peaceful, where groups and individuals struggle for dominance. The state with its varied means of control has a powerful impact upon society and political decisions go a long way towards determining who has power, wealth and prestige. Most importantly, politics is used to maintain social and economic inequality. Hence, the continuous debate on the cost of governance in Nigeria which deliberately have been skewed to benefit the politicians.

Party politics is only possible because, some individuals or groups have decided to come together with what they believe in, in order to capture the state control. That group belief is what is regarded as ideology and the term ideology is closely related to subculture but it had added connotation of self-justifying beliefs for a particular group. Hence the widespread differences between the so called opposition parties, especially the Action Congress of Nigeria (ACN) party and Peoples Democratic Party (PDP) in Nigeria.

Quite often too, ideology suggests hypocrisy, lies deliberate manipulation of the highest order, but the term is 
subtle. All of us like and perhaps need to believe that our position is explainable and justifiable. The term ideology builds upon the fact that our social position shapes our mental outlook and that human beings constantly seek explanations and justification. Although ideological explanations may be self-satisfying, they are not necessarily hypocritical or deliberately manipulative. Some times, they are sincere, though limited views, which grow out of social placement for example given the fact that I am a teacher, I am predisposed to think that learning is important or much more important than any other thing under the sun.

\section{Conceptual Framework}

Having highlighted these basic issues as our background, it is within democratic space that different views could be heard in the public sphere. What this model offer is that claims and counterclaims can be voiced out and thus conflicting claims and interests can be resolved in a non violent way. That is the beauty of democracy. From experiences and empirical evidence, it has been found that democratic order tries to accommodate competing visions of good life since all competing views about good life are scrutinized in the public where there is an undistorted communication among participant in the ideological space. The understanding in the game of politics instills the political virtues of freedom, equality and justice in the citizenry. These political virtues allow or make possible the principle of tolerance in the polity because different identities are recognized and different views are accommodate, laying the background for good governance for the common good.

According to Dewey, the expression of difference is not only a right of other persons but it also enriches other life experience. Democracy does not impose authority from above or the high heavens, but instead relies on the dialogical process as the source of authority and the means of choosing among competing alternatives. He believes that this process is a continuous one and its terminus cannot be designated or known in advance of democratic experience in which all share and to which all contribute.

From the above analysis, it is obvious that both intra and inter party conflicts as the topic suggest is natural, endemic and unavoidable, therefore must be contained and studied for better understanding and reaping of the necessary dividends. In the current democratic process, it is abundantly clear that intra party conflicts have resulted in shaping the current political tempo and harmony between the executive and the National Assembly. It did expose the politicians especially those who feel that they are indispensable thereby creating greater awareness among the electorates. Durkheim (1977), contends that pluralism is an important aspect of democracy since it brings about diversity and acceptance of differences in opinion. These differences of opinions can then provide ways of testing alternative $s$ through rational debate on good governance or the absence of it in any polity.

Intra-Party Conflict is a conflict within a given political party. It is the usual natural conflict of human beings to struggle for that limited social value within the group in terms of prestige, wealth, positions even recognitions. Most of these struggles are on selfish ground, sometimes collective but are carried out through the processes of sycophancy, name-calling, sabotage, sell outs, and other negative behaviours in order to be noticed, settled or destroy the collective gain of the party. Sometimes too, they are caused by some element of usurpation, tight handedness, unnecessary rigidity of party lords over members, greed, and some other personal idiosyncrasies of leaders.

A close call at the Western Nigeria crisis of 1965 succeeded in reducing the thin god status of Late Pa Awolowo by Akintola, thus producing new party and increased the political awareness of the region ever since, and which no region has been able to match in Nigeria. It generated from intra party conflict to inter party later on.

One of the major problem of intra party conflict is the idea of trying to cast everybody or member into one mould, philosophy or belief. But in the great democratic nation of United States, elements of intra party conflicts abound with the existence of liberal democrats and republicans. It is the contending issues that bring about intra-party dissent in party politics.

Inter-Party Conflict, on the other hand is an obvious, expected conflict because of differences in formation, leadership, manifestoes and ideologies competing to control the state in a democratic set up. The differences serve as springboard for individual ambition, factionalism, ethnic and religious bigotry, crisis of confidence and finally the quest for power control. It is the inter party conflict that make democracy possible and thick, thus these variegated groups wearing different ideological colours that come together to form parties. Given the internal dynamics of the parties, and the inherent ideological contradictions, political observers do predict inevitable conflict in party formations.

\section{Good Governance}


Good governance is about effective, visionary, transparent, trustworthy and credible political leadership whose driving force is an improvement in the collective wellbeing of the citizens, through well-conceived, effectively implemented economic policies and human development programmes (Kayode, 2012). The underlying principle behind good governance is the focus on people as the ultimate objective of development. Good governance, therefore, co-terminus with and determined by the quality of life and living conditions of the people, usually measured and evaluated by a combination of "governance indices" which include, among others, provision or facilitation by government, under its social contract with the people, of basic social services and economic infrastructures. In addition, food security, security of lives and property, level of unemployment and household incomes, human rights (which include rule of law, social justice, equity and fair ness, all of which ultimately lead to a peaceful and an egalitarian society), general level of want and poverty, hunger, ignorance, disease, as well as a general sense of deprivation, despair, frustration and uncertainty amongst the populace, all indicate the level of good governance, or the lack of it, in any country.

\section{Its Implications in Niger Delta Region}

A critical appraisal of democratic evolution will reveal that most of those who decided to engage in politics from the other geopolitical or regional lines in the country in the past do so with the collective interest of their ethnic and sectional nationalities as paramount concern. The other regions within the country have continued to function individually as a united block interested principally in ensuring that they put themselves in a vantage position when political calculations are made. The Niger Delta man sadly ha s not be en able to come together and achieve the unity of purpose. While the candidates for the other ethnic groups in the country are seemingly calculating on how they can bring the national government closer to their people, the Niger Delta politicians or candidates in the past are merely calculating on how they can position them selves as compromise or bargaining candidates with the assurance of acquiring for themselves better individual political appointments which will only benefit their own ambitions. Perhaps this is a harsh statement or analysis but the indices on the ground support this summation to a large extent. In any case west ill have some crop of good ones around us.

In the past republics, we have not been opportuned to be part of the intra or inter party conflict because we did cast our hope in one basket, thus, those who played politics in Niger Delta land were seen as tin gods, not vast in the game of politics, never had good opposition within, their opinions were never questioned and were good and therefore Niger Delta people never saw alternatives at all. Also many were not involved in party politics, those that were involved, only a negligible few were educated thereby couldn't attract enough benefits to their region, others were contractor politicians with less education. In essence positions given to Niger Deltans were token. This is because the few educated had no godfathers in politics, hence could not grow beyond their immediate environment and the dictates of their external godfathers. Niger Delta as group have a strong disdain to any individual or group found on the other side of the party line, therefore making it difficult for growth of party politics in the region.

But today a lot have changed, the fact the region has produced so many worthy candidates for some enviable positions in party politics recently as an indication of the coming of age of the regional group. But the fact also remain that some of these candidates are all scattered and fought one another in the last primaries and other stages within their parties, show that the Niger Delta man has still not learnt from the simple maxim "Divided We Fall" may not always be correct, because, we have also seen that there is "strength in diversity" which is the hallmark of democracy. The two maxims are not totally wrong or right. They are relative, depending on the side more dividends is beings accrued to a group. This is not to say that no Niger Delta man is being touted as big enough to become the president of the Federal Republic of Nigeria in the past was an insult on the political sensibilities of the Nigeria Delta people. This today has become a reality.

The fact remain that intra and inter party conflicts have a lot to offer to Niger Delta people because they border on quest for power and other considerations which are inevitable in the political process. In this nascent democracy of ours, intra and inter party conflict had led to the emergence of some strong vocal groups of all sexes that infact energized the political outlook of Niger Delta to a height never seen before. With good educational background and dynamism in politics, the issue of intra party conflict specifically has given us a lot of political harvest; we have not seen as a group and I hope the readers can testify to this fact of history. Even in the next political dispensation Niger Delta Region has come to be a force to be reckoned with by the other regions.

It is on record that with the gains of intra party conflicts, we are witnessing a great lot of strong political awareness, rejuvenating the zone to the highest climax: whereby issues of collective consensus and mutual benefits are becoming entrenched in the minds of our people and this ideas of political exclusiveness that once characterize our people and 
hunted us in previous participation in politics are becoming things of the past.

\section{Current Experience}

Intra-party turbulence in many of the political parties points to the undemocratic nature of selection of candidates for political offices. The few high-ups in the hierarchy determine winners and losers at the expense of their party's cohesion. It is no wonder, therefore, that political parties all over are having so much internal troubles that their orderly growth and development into a veritable resource magnet for political thinking and actions are being stymied. The political environment ever since 1999 still is very much in a confused state, thus service to the people is thrown to the winds (Guobadia, 20x12).

It is out of the confusion that some of the politicians were catapulted into office and it is the reason their behaviour is so anathematic since their loyalty is automatically owed to those who engineered their ascent. Politics in Nigeria has become a business enterprise in which the investors reap abundant profit at every available opportunity; fair or foul. These profits don't come from salaries and allowances alone (though bloated) but from a host of other cleverly devised means, bribery, contract inflation, security vote and oversight function. Unfortunately, the time spent in scheming out these new ways and implementing them leaves the wayward politicians so little time for serious governance and legislative work. Perhaps this is why Bayart (1992) has referred aptly to the struggles for democracy as expressed in the contest for political control of the state in Africa as "politics of the belly". Also, one therefore understand why an attempt to confront Nigerians on good and practical democracy is derided with the popularly cynical rhetorical question - "na democracy we go chop? (Kuka, 2003).

It is the reason why series of National Assembly investigative panels are yet to yield any benefit to the people or culprits found guilty; rather, they back to the house and peoples; docile attitude continue to manifest. Ake (2003:67-68) confirming the above on the lackluster attitude that Nigeria is still a contested terrain of conflicting identities even after four decades of independence and a still longer period of being one political entity. Possibly some of Nigerian elites think of themselves primarily as Nigerians and place their Nigerian identity above all other identities. But many more are ambivalent about what their primary identity should be. And even more place their Nigerian identity below their local community, nation or ethnic group. In Nigeria, as in most African countries, the state remains a battle ground where individuals fight for whatever power or resource they can capture. It is not surprising therefore that the hyped NNPC, oil subsidy, pension and many other probes are ladenned with a lots of misgivings, doubts of any tangible outcome.

Regrettably, however, Nigeria has become a land where honour means nothing and it means nothing because certain bad behaviour(s) have successfully been institutionalized. So calling anyone to resign because of a perceived taint on his character is akin to beating drums for the deaf. But all is not yet lost as the system can self-correct or be forced to correct itself.

\section{Problems of Good Governance}

The problem of good governance from the elitistic angle is the ascendancy of the comprador bourgeoisie the rule by merchantilist political middle class - (who do not consider the people or common man in their agenda or policies). These are people who see a political party as a trading commodity, buy them off and use them to win elections, only to turn around to milk the treasurer compradors are merchants, usurers, feudal lords and tribal aristocrats who are against national interest for either personal or ethnic advantage. (Amucheazi, 2013). This is well exhibited by the budgeting pattern whereby capital budget is far lower than the re-current expenditure which is the avenue public treasury is looted by politician in collaboration with their public officers and therefore issues like electricity, good road, health, education unemployment, and water which bother the populace are taken with kit gloove. Unlike what happens in United Kingdom where you have the independence office of Budget Responsibilities whose figures are independent of government, chaired by a respected professional and not a civil servant. Every mature democracy (towards good governance) sees the need for a reliable and trusted objective statistics agency. This will make if easier to at least agree (regardless of political affiliation) on the basic state of our economy without political tint according to Omole (2013). Obviously the current statistical organization and all other agencies involved in budget matters in Nigeria is too wedded to the government of the day. There is also doubt as to its composition. Probably, there is why in Nigeria, these is a general distrust in government and also lack of credible and independent financial report(s) emanting from government agencies.

Amacheazi affirmed that until political re-engineering gives birth to a system that would allow equality in political 
parties, true democracy would never come Nigeria's way. Genuine participation in governance will breed trust, engender commitment and contentment among people and lead to the much desired political stability. He also contended that the existing structure of the federation engenders ethnic, religious political parties which must be addressed if we must achieve meaningful growth and good governance.

Good governance in Nigeria. Finally the democratization of governance (though not yet in place in our system) must start with the party which is the agency for recruitment of political leaders who invariable governs. Thus, it is difficulty to expect good governance via responsive and responsible leaders if the agency that sponsors them is itself undemocratic. Governance framework is there to encourage the efficient use of resources and equally to require accountability for the stewardships of those resources. The aim is to align as nearly as possible the interests of individuals, corporation and society.

\section{Conclusion and the Way Forward}

The country and region are now in the midst of fervent debate about how it should sustain this fledging democracy. In other words, what social order can we evolve given the fact of our pluralism in party participation, how can we adjudicate competing or conflictual views and formulate and institute political policies without having widespread or severe dissent among regional politicians in the future dispensation? How can we evolve a well-ordered and articulated regional politician and group, which respect diversity? On what compromise can political discourse pertaining to the group proceed if our ethnic group is going to rule out the use of force to put an end to diversity within us? According to Ralws, such a society must evolve a consensus that includes not only substantive principles of justice, but also of a conception of public reason that Niger Delta people will use when articulating and justifying claims and proposals for resolving conflicts, this Ralws called the "idea of overlapping consensus".

The time has come for the Niger Delta people to see this idea of overlapping consensus as a sign of good thing to come, bearing in mind that a well informed, better educated, vast and current politicians are in abundance now, thus never again shall we cast our hope in one basket but should harmonise these shades of political views and linings for the benefit of the region.

Issues of Niger Delta cannot be discussed in isolation to what happens elsewhere in Nigeria and even internationally.

We cannot underestimate the importance of the opposition in a thriving democracy because it is believed that to reap the full benefits of democracy strong and vibrant opposition must be in place. However, ordinary citizens looking for good governance must be careful not to be used by opposition for their sinister gains. In all we must separate opposition politics from private citizens demanding better leadership and divided of good governance and democracy.

Many studies have shown that a nation's economic growth and quality of governance are enhanced by having leaders who are well-read, competent with the right leadership skills, exposure and behaviour. All the same, it is a general belief that a well-educated leadership is a competition advantage for any nation and there is a correlation between good governance and leaders' level of education. It seems this theory is not working in Nigeria. This means that leaderships arrays of certificates does not matter but the individual character and behaviour.

Changing the character of our polities is paramount and our roles and responsibilities as citizens are very critical to the issues of good governance. Thus some minimum citizens intervention, actions, engagements and initiatives are required to enhance good governance.

Accordingly, in order to entrench good governance and best practices, the leadership must ensure that development efforts, policies and programmes of government truly represent and reflect the needs, desires, yearnings and aspirations of the citizenry and are influenced by the people for whom they are supposedly designed. This is enhanced when the government have the capacity to listen also. Also, to achieve good governance, the tenets of a true federal system of government must be truly adhered to and be seen to be working. Indeed, the absence of true federalism is one of the reasons people have been clamouring for an (SNC) Sovereign National Conference, Resource Control, Fiscal Federalism Etc.

Furthermore, in order to achieve true federalism, there must be a distinction between the sharing of power and rendering of services among the federal and state governments, in order that the interests of majority of Nigerians, especially those at the grassroots, may be adequately catered for. There must be equal opportunities (equal rights) for all Nigerians, irrespective of their states of origin or religious back-grounds. More importantly, government's development efforts, or what is known as dividends of democracy, must trickle down to the people so that they can "feel good" and have a sense of belonging that they have a caring government. Ensuring the socio-economic comforts of the people is, 
therefore, the surest indication and the real challenges of good governance, Kayode (2012). In line with Hobbes Theory of Social Contract, where there is good governance, the people see themselves as government and are therefore motivated to pay their taxes voluntarily which encourages government to provide more infrastructure for the common good of the people, Nwachukwu citing Afflu (2013).

The ordinary Nigerians are not interested in the tribe, region or religion of who governs them. They are not interested in any cosmetic, obtrusive or elitist debate or talk shop in the name of national conference or whatever name, be it sovereign or otherwise. They are most interested in the level to which their elementary human needs are met. They are more interested in the "bread and butter" on their table and quality of life government can being to their doorsteps. Good governance has been the missing link in our polity, over the years. Going forward, the panacea for our national malady - be in corruption, insecurity, socio-economic and political problems - is simply good governance through effective leadership. I strongly believe that if we are able to achieve some measure of good governance, then we should be free, to a large extent, from the shackles of avoidable political wrangling and instigated ethno-religious crisis. Unless and until governments at all levels in the country - federal, state and local - begin to harness and direct efforts and resources towards the economic and social development programmes that will significantly enhance the lot and markedly improve the welfare of the citizens, I am afraid, the resultant social impoverishment and general level of poverty will continue to fuel political agitation and crisis.

\section{References}

Ake, C. (2003). Democracy and Development in Africa. Ibadan Spectrum Limited.

Amucheazu, E. (2013) Funding System: Bane of Nigeria's Political Party System Convocation Lecture Rivers State University of Science and Technology Port Harcourt $29^{\text {th }}$ April.

Bayart, J.F. (1993). The State of Africa. The Politics of the Belly. London: Longmans.

Braun, B. (1975). Political Accommodation and Consociational Democracy. British Journal of Political Science, 4; 502-503.

Daw, R. (1975). Government in Political Opposition. In Greenstein and Polisby, Handbook of Political Science, Vol. 3, Addison Wesley: Massachusetts Publishing Company.

Durkheim. E. (1977). St. Simons on the Origin of Society and Scientific Sociology. New York: Macmillan.

Goubadia, E.I. (2012). Politics Incorporate. Business Day, Wednesday, March.

Kayode, O. (2012) "Fixing Nigeria: Good Governance as the Missing Link" Business Day Monday 17 September.

Kukah, M.H. (1999). Democracy and Civil Society in Nigeria. Ibadan: Spectrum Books Limited.

Lizphart. A. (1977). Democracy in Plural Societies. A Corn Exploration. New Haven and London: Yale University Press.

Nmom, O.C. (2012). Niger Delta Region of Nigeria in Crisis. A Paradox of Historical Perspectives (in press).

Nmom, O.C. \& Igbanibo, S.T. (2006). Culture and Civilization: Social Science Perspective. Port Harcourt: Nissi Publishing Company.

Nmom, O.C. (2003). Interpreting Social Problems and Public Issues in Nigeria. Port Harcourt:

Nmom, O.C. (2013). The Problem of Ethnic Integration and the advent of Oil. The Case of Rivers State in Historical Perspectives (in press).

Nnaji, J.O. (1997). To Hell with Democracy. Enugu: Fourth Dimension Publishers Limited.

Nnoli, O. (1994). Introduction to Politics. London: Longmans.

Nwachukwu, I. (2013) "Good Governance Encourages Voluntary Payment of Texas" Business Day Friday 12 May.

Okoli, E.F. \& Okoli, J.F.C. (1991) Founbdations of Government and Politics. Onitsha: Fed Publishers.

Omole, C. (2013). In Pursuit of Credibility in Government. Business Day Tuesday 23rd April.

Otten, M.C. (1981). Power, Values and Society. An Introduction to Sociology. Greenview, Illiois: Scott, Foresman and Company.

Poton, G. \& Gill, P. 1993). Introduction to Politics. Oxford: Blackwell.

Ralws, J. (1971). A Theory of Justice. Combridge: Mass Harvard University Press.

Sibe, R. (2013) Nigeria In Need of Shock Therapy (s) Business Day Thursday $7^{\text {th }}$ March. 